\title{
JLEET
}

Journal of Language Education and Educational Technology

Volume 6 No. 1, 2021

e-ISSN: 2502-3306

\section{The Expressive Language Skills of a Bilingual Child: A Case Study}

\author{
Risnawati, Nurnia, Ader Laepe
}

Halu Oleo University, Indonesia

\begin{tabular}{|c|c|}
\hline ARTICLE INFO & ABSTRACT \\
\hline $\begin{array}{l}\text { Keywords: } \\
\text { The expressive } \\
\text { language skills, Mean } \\
\text { Length of Utterances, } \\
\text { Bilingual child } \\
\text { DOI: } \\
\text { http://dx.doi.org/10.33772/jleet.v6i1. } \\
16028\end{array}$ & $\begin{array}{l}\text { This study attempted to explore the expressive language skills } \\
\text { of a bilingual child from year to year. A qualitative method } \\
\text { was used with the support of simple analysis of Mean Length } \\
\text { Utterances calculation to answer the research question. The } \\
\text { data was taken from the transcribed videos recorded } \\
\text { intermittently from } 2015 \text { to } 2020 \text {. Initially, the MLU score of the } \\
\text { child was only } 5.7 \text { and it did not reach the standard score of } \\
6.88 \text { for her age. However, the child's MLU score for the } \\
\text { following years rose even higher than it should be. The whole } \\
\text { words of each utterance were counted then divided by the } \\
\text { number of utterances. Based on the data, there was no } \\
\text { significant improvement in } 2019 \text {. This might be due to the fact } \\
\text { that the data available in } 2018 \text { was of monologue type and that } \\
\text { the subject was less willing to speak back then. Furthermore, } \\
\text { based on the researcher's observation, the English proficiency } \\
\text { of the child, especially expressive language skills mastery, } \\
\text { increased from year to year. Besides, the child was also shown } \\
\text { to be more motivated. She kept practicing her English with her } \\
\text { sister by watching and making English videos and acting as a } \\
\text { professional Youtuber. }\end{array}$ \\
\hline
\end{tabular}

\section{INTRODUCTION}

English has already become one of the most widely taught, learnt and spoken in the world today. It is used as a first language by over 300 million people in Australia, 
Canada, New Zealand, the UK and the USA, and as a second or foreign language by over 700 million people in the countries of Africa, Asia, Europe, and Latin America, and of the island nations of the world (Kachru \& Nelson, 2006). Because the number of English users (both native and non-native speakers) is high, the use of English as the medium of

communication between those people who have different cultural backgrounds is unavoidable. This condition automatically makes English as a lingua franca. The use of

English as a lingua franca makes many people around the world use English to communicate, although English is not an official language in such countries. They believe that mastering English will improve their life quality and also improve their career in the future. This also leads many parents to expose their children to English in the early age.

Additionally, this massive use of English forces many people to master English to facilitate communication across nations. The government also takes part on this matter by introducing English as one of the mandatory subjects in school curriculum from elementary to higher education. They hope that the citizen can have good command of

English. However, those efforts seem useless since many students fail to sustain communication in English even it is only for daily communication.

However, in some cases there are several children who learnt English effortlessly. They learnt English within a short period of time since they live in an English-speaking environment like Malaysia, or children who come to international school in which English is the language of instruction in the school. Such condition can be found in big cities where professional teachers or native English speakers are employed. However, in some cases, a child masters English in the early age within English as a foreign language context. She does not come to international school for the support of their English language mastery since she lives in a remote area, but her command in English exceeds the average children's English command. This case happens to a child living around the researcher.

This child has already been able to use English to express herself for daily communication and also for several transactional communications in English. She also could demonstrate the use of English with a good pronunciation near native. The researcher herself was curious on why she could have such kind of English mastery which was beyond her English play mates in their age. Most of the kids she played with in the neighbourhood do not show a good command on English. This study focused on examining the development of expressive language skills of this child.

\section{LITERATURE REVIEW}

Richards and Schmidt (2002) define language acquisition as the learning and development of one's language. The first language learning of a native speaker is called first language acquisition, while language acquisition after he masters the first language is said to be second language acquisition.

Krashen (1981) makes the difference between acquisition and learning. Both refer to the process of acquiring language, but differ in several ways. Acquisition refers to processes that occur unconsciously to the internalization of language rules obtained from language input that is understood when the attention of language learners is focused on 
mere meaning (focus on meaning), not on language forms (focus on form). And this is more common in the context of second language learning. Children who acquire their second language from their environment such as friends, neighbours, school, and others can be said to acquire language. Conversely, a child who learns language through formal instruction in the classroom is said to be learning. This is because the learner of the language is aware of what he is doing through an explicit study of the rules of language and their use, as is typical of language classes that function as foreign languages. In short, the acquisition of language as a second language is acquisition, while the acquisition of language as a foreign language is learning.

However, Richards and Schmidt (2002) limit that "acquisition" only occurs in the process of learning the first language or mother tongue. On the other hand, some experts actually use the terms "learning" and "acquisition" synonymously. The dichotomy between acquisition and learning is better known as the acquisition learning hypothesis (Mitchell \& Myles, 2004).

Expressive language refers to the capacity of a child to communicate themselves through language. Each time a child expresses his desires, feelings and ideas to another using signs, phrases, or sentences, a child uses descriptive language (Kid Sense Child Development Corporation, n.d.). Expressive language is a very broad concept, however. We split down spoken language even more into three different sections as speechlanguage therapists: semantics, grammar, and morphology. We do this so that the key topic can be properly defined and handled. For starters, some kids can have vocabulary problems. They do not have phrases that they use to associate with people yet. Or, they may have a very small vocabulary, or some of the time they might be able to understand phrases, but sometimes they might have trouble 'finding' the words. This type of vocabulary problems fell under the field of grammar of expressive language.

Some kids can have problems using what we usually think of as "grammar," or the vocabulary of descriptive language. Such kids might use shorter sentences and phrases than we expect for their age. Or, they may find it difficult to have the words in the correct order, or they may miss out the short, grammatical pieces of language that have a major meaning like the "ing" in "Joey's walking" or the possessive $-\mathrm{s}$ in "Daddy's shoe. They usually adopt a general trend of acquisition as children acquire expressive language. In other words, at a certain age, they usually acquire expressive language skills one after another, in a certain order.

\section{METHODS}

Since this study applied an empirical inquiry that investigated a phenomenon within its real-life context and based on an in-depth investigation of a single individual of a child to explore the causes of underlying principles, the researcher will use a case study method to search for the answers on the research questions proposed in this study. According to Borg and Gall (2003:433), case study is a type of research which is a mostly widely used approach to qualitative research in education. "The qualitative case study can be defined in terms of the process of actually carrying out the investigation, the unit of analysis (the bounded stem, the case), or the end product" (Merriam, 2002). A 
case study is an exploration of a "bounded system" or a case (or multiple cases) over time through detailed, in-depth data collection involving multiple sources of information rich in context (Cresswell, 1998). The qualitative case study can be defined as an intensive, holistic description and analysis of a single entity, phenomenon, or social unit. Case studies are particularistic, descriptive, and heuristic and rely heavily on inductive reasoning in handling multiple data sources (Merriam, 1988;16). This research is perfectly matched with this type of research since it deals with several types of data sources namely observation and interview through detailed and in-depth data collection on particular object of study namely a child who lives in an EFL context with her own characteristics of language mastery. The data on this study obtained through observation was video recorded, and then transcribed. After being transcribed, then the size of the Expressive language skills production of the child was measured by using Mean Length of Utterances (MLU) test.

In this study, the Mean Length of Utterance calculation was done by counting the number in each utterance and noting the total of words, syllables, and morphemes under each sentence. Then we will have the total of for each utterance average the totals with the number of utterances to find the MLU. Here are some rules for calculating mean length of utterance based on Brown (1973):

a. Using fully transcribed utterances only; none with blanks. Portions of utterances, entered in parentheses to indicate doubtful transcription, are used.

b. Including all exact utterance repetitions. Shuttering is marked as repeated efforts at a single word; Count the word once in the most complete form produced.

c. Fillers as mmm or oh are not counted, but no, yeah, and hi are counted.

d. Counting all compound words (two or more free morphemes), proper names, and ritualized reduplications as single words. Example: birthday, rackety-boom, choochoo, quackquack, night- night, pocketbook, see saw. Justification is that no evidence that the constituent morphemes function as such for these children.

e. Counting all irregular parts of the verb (got, saw, went, did) as one morpheme. Justification is that there is no evidence that the child relates these to present forms.

f. Counting all diminutives (doggie, mommie) as one morpheme because these children at least do not seem to use the suffix productively. Diminutives are the standard forms used by the child.

g. Counting all auxiliaries (is, have, will, can, must, would) as separate morphemes. Also all catenatives: gonna, wanna, hafta, This latter counted as single morpheme rather than as going to or want to because evidence: Is that they function so for the children. Count as separate morphemes all inflections, for example, possessive(s). plural (s), third person singular(s), regular past(ed/d), progressive (-ing).

Brown (1973) offered the formula of MLU as follows:

$$
\text { Mean Length of Utterance }=\frac{\text { Number of Morphemes/words }}{\text { Number of Utterance }}
$$


After finding out the MLU, what we need to do now is determining the age at which the majority of children would present with a mean length of utterance equivalent to the one of particular child has been scored. This is known as the age equivalent. We do this by reading off the age equivalent in Table 1 . From the table, we see that an MLU of 4.25 lies between 4.09 and 4.40. We can conclude, then, that an MLU of 4.25 would be expected in a child of between 45-48 months of age. As we know that our particular child is 48 months old, then it appears that the average length of the child's utterances is age appropriate. This suggests, therefore, that this child's expressive language skills are developing along typical lines.

Table 1. Age Equivalent adapted from Miller (1981)

\begin{tabular}{|lc|}
\hline Mean Length of Utterances & Age (month) \\
\hline 1.31 & 18 \\
\hline 1.62 & 21 \\
\hline 1.92 & 24 \\
\hline $\mathbf{2 . 5 4}$ & 30 \\
\hline $\mathbf{2 . 8 5}$ & 33 \\
\hline $\mathbf{3 . 1 6}$ & 36 \\
\hline $\mathbf{3 . 4 7}$ & 39 \\
\hline $\mathbf{3 . 7 8}$ & 42 \\
\hline $\mathbf{4 . 0 9}$ & 45 \\
\hline $\mathbf{4 . 4 0}$ & 48 \\
\hline $\mathbf{4 . 7 1}$ & 51 \\
\hline $\mathbf{5 . 0 2}$ & 54 \\
\hline $\mathbf{5 . 3 2}$ & 57 \\
\hline $\mathbf{5 . 6 3}$ & 60 \\
\hline $\mathbf{6 . 8 8}$ & 72 \\
\hline $\mathbf{8 . 1 2}$ & 84 \\
\hline $\mathbf{9 . 3 6}$ & 96 \\
\hline $\mathbf{1 0 . 6}$ & 108 \\
\hline $\mathbf{1 1 . 8 4}$ & 120 \\
\hline $\mathbf{1 3 . 0 8}$ & 132 \\
\hline & \\
\hline
\end{tabular}




\section{FINDINGS AND DISCUSSION}

\subsection{Findings}

The data was gathered through observations which were video recorded for 6 years. For more brief understanding in obtaining information about the vocabulary development of the child, the writer presents the following table which shows the result of MLU calculation from year to year.

Table 2. MLU Test of the Child within 2015-2020

\begin{tabular}{|lll|}
\hline Year & Age & MLU test \\
\hline $\mathbf{2 0 1 5}$ & 6 years & 5.7 \\
\hline $\mathbf{2 0 1 6}$ & 7 years & 9.6 \\
\hline $\mathbf{2 0 1 7}$ & 8 years & 13.3 \\
\hline $\mathbf{2 0 1 8}$ & 9 years & 23.5 \\
\hline $\mathbf{2 0 1 9}$ & 10 years & 18.3 \\
\hline $\mathbf{2 0 2 0}$ & 11 years & 31,14 \\
\hline
\end{tabular}

From the table above, we know that the data began in 2015, the age of the child was six at that time. Based on the data, the score of the child only 5.7 for MLU test and it did not reach the standard score which is expected. However, the child's MLU score for the following years increased base on the age and even higher than it should be. In 2015, 20 spontaneous exposures were involved in this calculation. The whole words of each utterance are counted together then divided by the number of utterances. The table shows us the improvement from year to year, except for 2019. This might be attributed to the fact that the data available in 2018 was of monologue type, so the subject's expressive language skills production was very high and it reached 23.5 for MLU test. The monologue caused long utterances because no one interrupted when the subject spoke. Another factor would be the willingness of the subject to speak. She herself made this video without interacting with others, so the writer assumes that she spoke with herself.

As far as the researcher is concerned, the expressive language skills of the child also was very rich. She did not only master the vocabularies which related to the children (toys, school stationary, animals, etc) but also all aspects she could respond. Furthermore, the mimicry, the accent of the child when she speaks is native like. Here is the detail description of the child's development from year to year.

\section{Table 3. Video Transcript of Child's Language Production in 2015}

Kolaka, 10 June 2015

1. My name is Faatihah Rizqy Risyah (4w/4m)

2. You can call me Icha( $5 \mathrm{w} / 5 \mathrm{~m})$

3. Today, I want to tell you about this picture. $(9 \mathrm{w} /$

4. Ica: Yes $(1 \mathrm{w} / 1 \mathrm{~m})$

5. Ica: No. $(1 \mathrm{w} / 1 \mathrm{~m})$

6. Ica: motorcycle $(1 \mathrm{w} / 1 \mathrm{~m})$

7. Ica: This is the picture of my school Kinder garden al Mawaddahwarrahmah, The fence is colorful (14w/15m) 
8. Ica : We can study about shape, reading, writing, drawing, painting, singing, counting, dancing $(12 w / 19 m)$

9. Ica: yes $(1 \mathrm{w} / 1 \mathrm{~m})$

10. Ica: This is the leader of my boarding school Kinder garden al Mawaddahwarrahmah $(10 \mathrm{w} / 11 \mathrm{~m})$

11. Ica: This is Miss Mar. She is a kind teacher(9w/9m)

12. Ica: Miss ria. She a kind teacher. She never mad $(9 \mathrm{w} / 9 \mathrm{~m})$

13. Ica: She is Ms. Jannah, she shows us how to dance and exercise $(11 \mathrm{w} / 12 \mathrm{~m})$

\section{December 2015}

14. Ica: ok $(1 \mathrm{w} / 1 \mathrm{~m})$

15. Ica: about what?(2w/2m)

16. Ica: I am singing? $(3 \mathrm{w} / 4 \mathrm{~m})$

17. Ica: okay okayokay! I remember my sing frozen(said so sassy)( $8 w / 8 m)$

18. Ica: oh.. ${ }^{*}$ giggles* $(1 \mathrm{w} / 1 \mathrm{~m})$

19. Ica: the movie with elsa? $(4 \mathrm{w} / 4 \mathrm{~m})$

20. Ica: oh I all done known about the stories $(8 \mathrm{w} / 9 \mathrm{~m})$

\section{The MLU Calculation: \\ $4+5+9+1+1+1+14+12+1+10+9+9+11+8+4+1+8+3+2+1=114 / 20=5.7 \mathrm{w}$}

The first monologue was taken on 10 June 2015. It was a farewell party. Faatihah Rizqy Risyah (the subject) was appointed to take a part in that event to show her ability in speaking English. The agenda went well since I myself stood beside to accompany her. The video shows that in her age of six, she had been able to respond the questions well. She could also arrange simple sentences, as we can see in the first minutes of the video, she introduced herself as well as her school and made a prolog of her performance.

The size of the expressive language skills that she produced at that time has not been appropriate base on the age, it only approached 5.7 by using Mean Length of Utterances (MLU) test as it is expected to have score around 6.88. However, it is normal thing for the bilingual child whose English is beyond her first language. The number of words could not be considered as the only one measurement to test her ability since the questions which were addressed to her just need simple words to answer. Consider the following questions:

"What can you study/ learn there(school)?"

"Can you count one to thirty?"

Both questions produce the big size of words/vocabularies; the first question was answered by producing 12 words by just mentioning the things which she learned at school without having to make any complicated sentences. Moreover, responding the questions of "can you count one to thirty, please? this automatically would produce thirty words to respond.

The video also shows us that in some occasions, she only responded by saying "yes" and "no". There are also some odd sentences as in "My friends can pick motorcycle or car" but it can easily be perceived that the intention of that sentence could be "My 
friends can be picked by motorcycle or car". This means that she had not been able to arrange passive sentence. Another odd respond would be in:

Mom : Do you study animals in your class?

Ica : No

Mom : about animals?

Ica : may be I can

She responded "No" when I asked whether she learned animals in her class or not but when I insisted by repeating the word "animals" she directly answered my question by saying "may be I can". However, this situation might be caused by the fact that there were hundreds of participants in front of her since she was on the stage at that time. Watching these videos in 2015, we can conclude that in her age of six, the child had been able to arrange simple sentence even to more complex sentences.

Table 4. Video Transcript of Child's Language Production in 2016

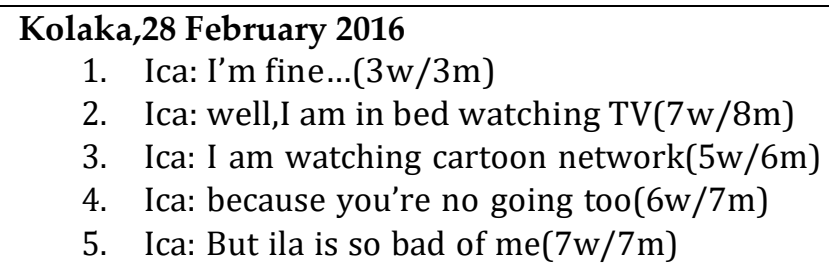

\section{1 august 2016}

1. Ica: (inhale)picture today on the laptop,computer.now,let's start coloring it!(12w/13m)

2. Ica: I am starting coloring of the ...uh...flame princess head $(9 \mathrm{w} / 11 \mathrm{~m})$

3. Ica: (think) flame princess $(2 \mathrm{w} / 2 \mathrm{~m})$

4. she all...(I mean) she have all powers of fire,if you want to colourit,jus go on!(while directing cursor)oooh this diamond....(19w/20m)

5. Ica: I love all of it(not use the word both)(5w/5)

6. Ica: re.....it's a jem!uh....it's just like beads in your shirt!(guessing)(12w/13m)

7. Now, let's start the red cause it's not just perfect, this is red! And this is the red too because every fire is....uh...red,yellow, and a....(little bit busy to explain while colour the picture in the laptop)(28w/28m)

The MLU Calculation:

$3+7+5+6+7+12+9+2+19+5+12+28=115 / 12=9.58 \mathrm{w}$

This video was taken on 28 December 2016, as usual; she greeted us in the beginning, and it was continued by asking her activity which is being done and she answered it very well. From this conversation implicitly we can know that she knows more English through watching because of her reason of the question "why do you like watching cartoon network?" she answered spontaneously that by watching it, she can know English. In this video, it appeared that in her age of seven she could have given reasons for some questions which were addressed to her. It suggests that she improved her ability in producing more complex sentences. 
As it was found in 2015, at the of 6, the MLU score has not approached the standard. However, in 2016 the score lies at 9.58 compared to the expected standard of 8.12. It means that at the age of 7 her MLU was higher than what was expected of her. Another thing that amazed the writer is that this child could understand different kinds of topic which are being discussed. As the example of this video on 21 August 2016, she spoke in English as if she were a tutor of art paint. She directed us how to draw and color in the laptop. The expressions or the words which she used do not only belong to the children but also to adult.

\section{Table 5. Video Transcript of Child's Language Production in 2017}

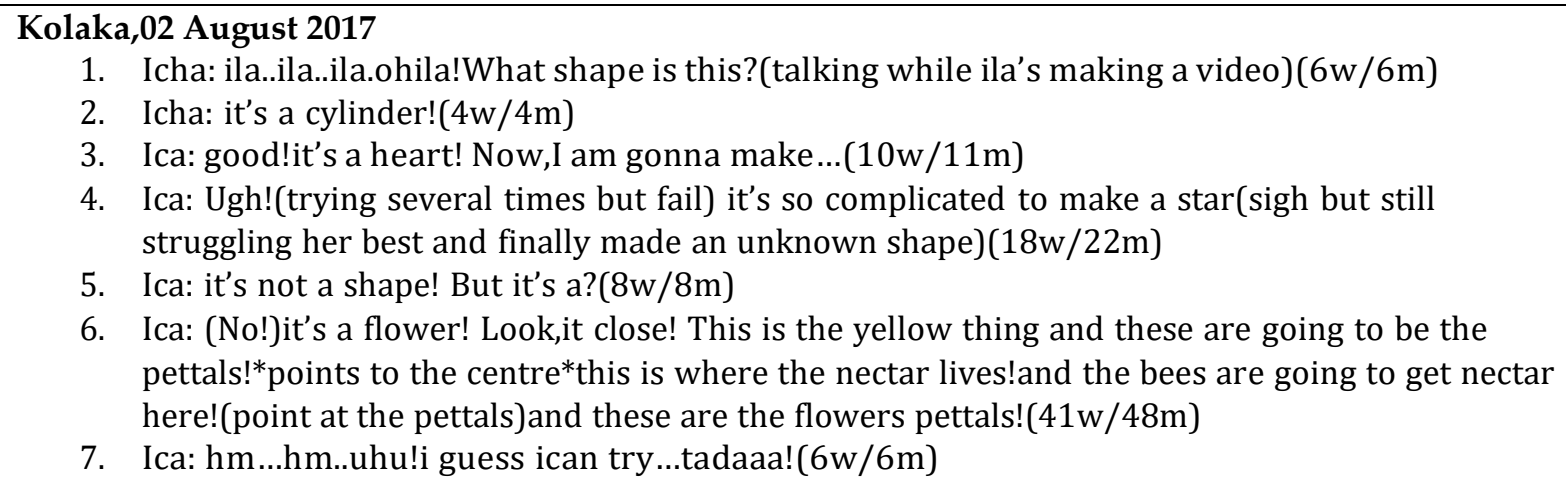

1. Icha: ila..ila..ila.ohila!What shape is this?(talking while ila's making a video) $(6 \mathrm{w} / 6 \mathrm{~m})$

2. Icha: it's a cylinder! $(4 \mathrm{w} / 4 \mathrm{~m})$

3. Ica: good!it's a heart! Now,I am gonna make...(10w/11m)

4. Ica: Ugh!(trying several times but fail) it's so complicated to make a star(sigh but still struggling her best and finally made an unknown shape $)(18 \mathrm{w} / 22 \mathrm{~m})$

5. Ica: it's not a shape! But it's a?(8w/8m)

6. Ica: (No!)it's a flower! Look,it close! This is the yellow thing and these are going to be the pettals!*points to the centre*this is where the nectar lives!and the bees are going to get nectar here!(point at the pettals)and these are the flowers pettals! $(41 \mathrm{w} / 48 \mathrm{~m})$

7. Ica: $\mathrm{hm} . . . \mathrm{hm} .$. uhu!i guess ican try...tadaaa! $6 \mathrm{w} / 6 \mathrm{~m})$

The MLU Calculation:

$6+4+10+18+8+41+6=93 / 7=13.3 \mathrm{w}$

It is clear that at the age of 8 , the child could already produce 13.3 words, an MLU of an 11 year old kid. The expected score for the 8 year child is only 9.36. Again, the video which was taken in 2017 showed that the child was very creative, she could shape any different kind of things then make it or imitate the common shapes like rectangle, star, triangle, cylinder, etc. In the end of this video, she tried to shape 'tasbih" to be a flower. In her explanation, we could know that she had been very familiar with the parts of the flower. She could mention the words "nectar" and "petals" and explain the position of both parts of the flower.

Another video in 2017 talked about various topics. The first was about game, she could mention the names of the game which are available in her phone. Besides that she could express the "simple past tense" well when she spoke. Once I asked her "what are you doing? Then she stopped playing game then answered my question "I was just playing game". Then I asked her again "how could you get that game?" She then answered" my friends gave me". It signs that she could positioned the sentence well. She used verb 2 "gave" to show that it was happened in the past time. Futhermore, she could be able to use "have" and "has" correctly. As we can see in "it has holes" whereas in some videos before she still use incorrect form, "have" for the subject "she".

However, there is a word which I considered a common word, but she did not understand; she seemed unfamiliar with the word "activity". When I asked "What is your activity?" she answered "Upin and Ipin" then I repeated my words "your activity" but 
she still did not understand, so I asked her again "What did you do?" then she could undertand and directly answered the question. The next topic of the video was about "visiting to the beach" so the discussion would not be very far from the things in the sea and the activity related to the sea "jelly fish, shark, crocodile, whale, wave, sand castle, swimming, jumping".

In the middle of this video we also know that the child could use conjunction to connect one sentence to another sentence like "instead", "but", "because,", etc. I am also impressed with her respond "I really love to but I don't want to go without you". At her age of 8 she already knew how to decline an offer politely - a topic that will only be learned by third year students of senior high school. The same case as this sentence "She only just loves swimming and making sand castles". This sentence shows that this child was very good at gerund, where she added "ing" at "swim" after verb "love" and still added "ing" after "make" because "and" is the conjunction to connect between swim and make which these two words need to be paralleled.

The MLU Calculation:

$2+4+62+39+6+8+7+56+25+7+45+21=282 / 12=23.5 \mathrm{w}$.

The calculation of MLU in 2017 shows that there is a significant increase in 2018. Based on the data on the video transcript, the following scores were obtained: $2+4+62+39+6+8+7+56+25+7+45+21=282 / 12=23.5 \mathrm{w}$. The score achieves 23.5 words, the expected score of that age level is only 10.6. It is beyond of our expectation, it is a half higher than it should be. This also might be due to the type of the talk. Even though there were two speakers, the subject talked more since her sister seemed unconfident to talk.

It is different from another video which the child was usually accompanied by her mother (the writer). In this case, she only talked with her sister. However, the talk was dominated by Ica, her sister just talked a little bit. Both of these children were so excited to have another new little sister. They also hoped some wishes for their mom pregnancy. She hoped to have adorable, cute baby sister.

She also hoped that the baby inside of her mom's belly could survive since the pregnancy before failed to bear. Even though there is only one video which we had in 2018, we could know that the development of the vocabularies was very good since she had different topic to talk about.

Table 7. Video Transcript of Child's Language Production in 2019

\section{Table}

13 April 2019

1. Ica:it looks ugly(3w/4m)

2. Ica: Because she got bullying at school $(6 \mathrm{w} / 7 \mathrm{~m})$

3. Ica: yes $(1 \mathrm{w} / 1 \mathrm{~m})$

4. Ica: Bullying is not $\operatorname{good}(4 \mathrm{w} / 5 \mathrm{~m})$

5. Ica: it's not right to do $(6 \mathrm{w} / 6 \mathrm{~m})$ 


\section{October 2019}

6. Ica: *looking at Ila's picture* Ila, what are you making? Let me read it...*inhales and reads* the heart world, how I look when I am a queen,heart in the world heart? What does that mean?*keeps reading* the natural world,how I look when I am a queen,heart of the world of natural.Um....seriously?your heart*picture*.it's kind of freaking me out! Here!Let me make it more adorable! (edits the picture) is that enough?(asking ila)(63w/67m)

7. Ica: Oh the queen that's not how I called a queen.can I get a design a little?(18w/19m)

8. Ica: Okay...I am gonna get her a bow... aribbon!and I am gonna give her hearts here and stripes...and more hearts!cause you are a heart queen! And this thing you gave her is a flower,not a heart!i am gonna give her hearts in the shoes,let's get heart in here,heart in there, oh my God there are so many hearts!*look at the picture again*Uh....what is this?this side has two dots and one side is look like one dot and one is a moon...(88w/97m)

9. Ica:What is this?*points* $(3 \mathrm{w} / 3 \mathrm{~m})$

10. Ica: a squingle?What's a squingle? $(4 \mathrm{w} / 4 \mathrm{~m})$

11. Ica:Like this?*drawing in the paper* $(2 \mathrm{w} / 2 \mathrm{~m})$

12. Ica: okay,fine!Let's get into the design!*look at ila* Uh...Ila,Your tie is too big $(15 \mathrm{w} / 15 \mathrm{~m})$ Ila:*giggles*

13. Ica: It's even bigger than my tie!*goes somewhere near ica* $(7 \mathrm{w} / 8 \mathrm{~m})$

14. Ica: Does this look good? $(4 \mathrm{w} / 5 \mathrm{~m})$

15. Ica: Is this enough?(3w/3m)

16. Ica: Oh let me add a pony tale! $(7 \mathrm{w} / 7 \mathrm{~m})$

\section{December 2019}

17. Assalaamu"alaikum,hello guys! I'm gonna introduce you to this new oil,Kutus-kutus!This oil can help you to reduce umm...fever, backache and a lot more. If you want to reduce the backache, just get this oil and spread it to the surface then massage it!if you have a fever,um...just spread it on your chest and your throat!Just do it a couple of times,and you'll be good!Stay healthy guys with Kutus- kutus(77w/82m)

The MLU Calculation:

$3+6+1+4+6+63+18+88+3+4+2+15+7+4+3+7+77=311 / 17=18.3 w$

The 2019 MLU was 18.3 words compared to 23.5 words in 2018's MLU. However, this score is still far higher than the expected score. The expected score lies around 11.84. The first video in 2019 was a very short dialogue. This video shows us that besides her ability in speaking English, the child is also very good at drawing. She drew a girl who is wearing Moslem wear with beautiful design but her face showed a deep sadness. According to Ica, the girl has got bullying at school. In this case, we know that, the world "bullying" had been familiar to her ears and she knew that bullying is not good or not right thing to do.

The second video was taken in 28 October 2019, as I mentioned before, the subject has good interest in drawing. This video shows us that she was reviewing her sister drawing. She added details which considered having not completed yet. If you watch this video, you might understand that the child was very jeli. She even added dots to the picture. Look at the following utterances! " Okay....I'm gonna get her a bow...a ribbon! and I am gonna give her heart here and stripes... and more hearts! cause you are a heart queen! and this is thing you gave her is a flower, not a heart! I am gonna give her heart 
in the shoes, Let's get heart in here, heart in here, oh my God there are so many hearts! The Expressive language skills which appeared in the dialogue was based on the picture that's being drawn. In this case, the picture was about the queen but the talks did not focus on that "heart queen", She was just busy editting the picture.

The third video is about the advertisement. She explained the benefit usage of the oil Kutus- Kutus. She explained it well as if she spoke Indonesian. She spoke very fluently. In this video we understand that the subject was not only good at responding the dialogue or short talk but also for making short monologue which of course need a full of concentration because we ourselves set the talk.

\section{Table 8. Video Transcript of Child's Language Production in 2020}

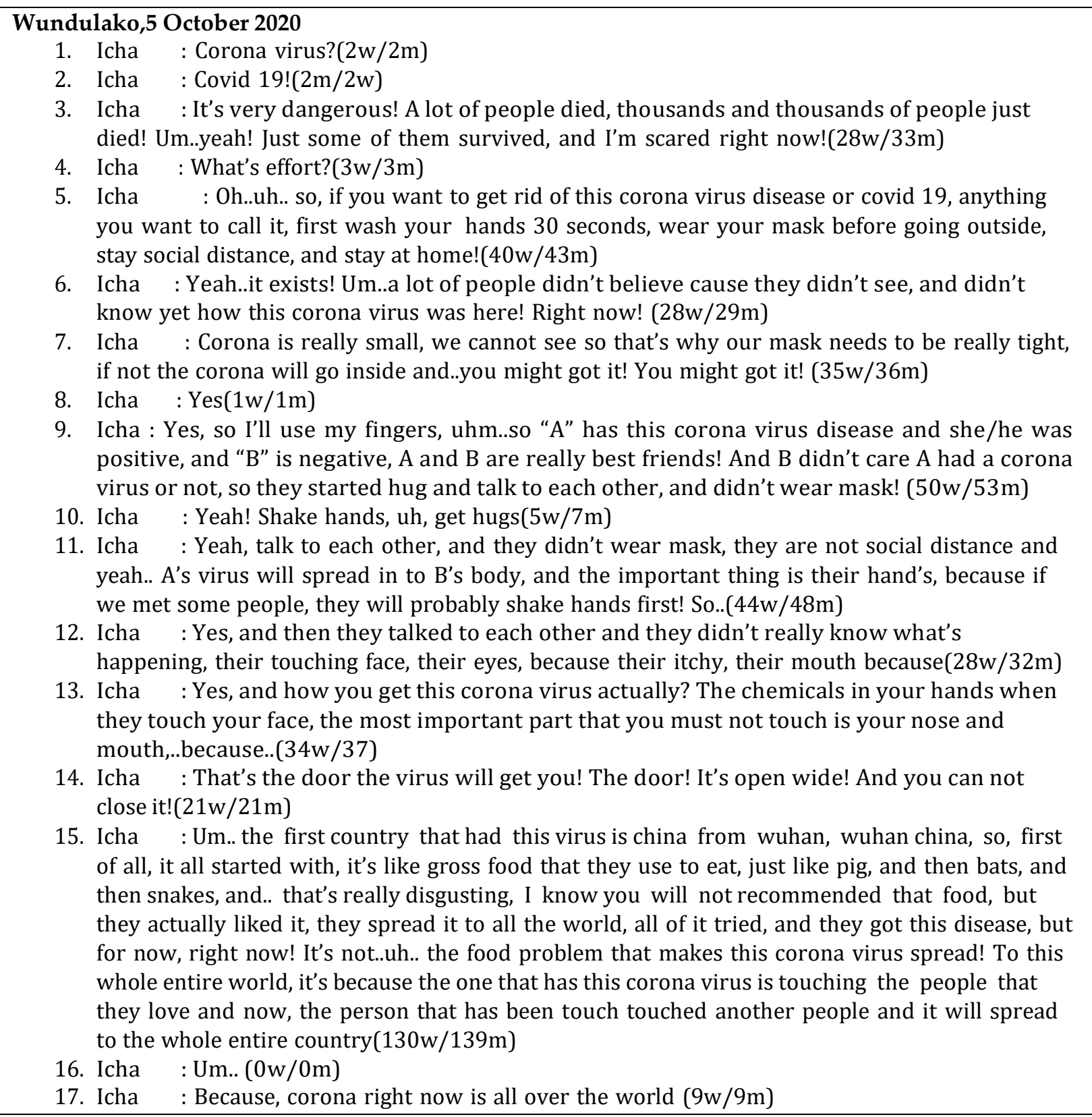


18. Icha : Yes, my teacher said, Allah SWT let this pandemic be, so they will, you know, learn more that this earth is getting older and it's all because their victory, as this corona pandemic thing arrived, the fabric start closing and there is no more pollution, although there is some more, but not as much as, you know, the few days past ago $(62 \mathrm{w} / 65 \mathrm{~m})$

19. Icha : Yes, uh..when I was home schooling, just like.. you know.. home schooling stuff that all they, um.. some people say, in my school, because my school is mixed with a cottage, some of the cottage person got negative, and they are going to hospitals, and I'm very scared, and I didn't wanna go to my school anymore, but in the end I did go there $(65 \mathrm{w} / 69 \mathrm{~m})$

20. Icha : A shame, um, I mean they didn't get much knowledge, because, maybe the teacher said " okay kids! You will solve from number 10-20, and remember! No google! No this! No that" but when they started working, they did use google and yeah.. that's not fair $(47 w / 50)$

21. Icha : No! google is a liar! $(5 \mathrm{w} / 5 \mathrm{~m})$

22. Icha : I mean, if I search for something, some weird stuff happened, even though I know what's the translate of this word, but if I started texting it on google, it was wrong.. it was incorrect, I ended up using my brain to solve that problem $(46 \mathrm{w} / 49 \mathrm{~m})$

The MLU Calculation:

$2+2+28+3+40+28+35+1+50+5+44+28+34+21+130+0+9+62+65+47+5+46=685 / 22=$ $31,14 \mathrm{w}$

In 2020, her English improved quite significantly. At the age of eleven years old, the MLU calculation reached 31.14 compared to 13.07 the expected score. The data analyzed was talking about the current issues which is discussed all over the world, that is Corona Virus Disease or Covid-19 for short. The writer believes that the improvement is caused by the subject herself. She keeps exploring the current issues, communicating with her sister and mom by using English, and watching more videos to expand her vocabularies in different contexts.

\subsection{Discussion}

The writer is also the mother of the subject. It cannot be denied that she played an important role in her daughter/subject's ability in acquiring her English mastery. As a young mother for her first daughter, of course she wanted to do the best thing that she could do at that time, including enabling her daughter to acquire English vocabulary in her early age.

The writer, who happens to be an English teacher, tried to communicate with her daughter using English. She always stimulated the child starting with the simple words like colors, things, etc to simple sentences. Besides that, knowing that the child was very interested in watching, her parents facilitated her some English discs like Dora, English songs which the child could watch them in laptop. In this case, the child got more vocabularies which were acquired in natural settings (Ellis, 2002; and Krashen, 1981).

Furthermore, the subject and family lived in the right environment. Both her parents were educators in Islamic boarding school. Her father was an Arabic teacher and her mother was an English teacher. They were crowded by the students who were obliged to speak only English and Arabic. This situation directed us to speak those two languages and of course this could affect the child in acquiring more vocabularies (Deeksha, 2007). However, unlike English, the child's Arabic mastery was not too good. 
The writer assumes that it was due to the activeness of the mother in raising up and taking care of her child. Mother tended to be more active and talkative than father. Besides, psychological closeness also became a factor.

In her age of three, she and her family moved to a new house. In this age, she had been able to know the colors and the specific things in her environment, she also knew simple verbs like drink, eat, watch, go, etc. So, to formulate simple sentences was easy thing for her like, I want to drink, eat cookies, watch TV, etc. In her new house, her parent subscribed to Okevision which provides Disney cartoon without subtitles. In this situation, the child was used to hearing and seeing original exposures from the native speakers without having to read the subtitles. As far as my observation, the child enriched her vocabularies through the program which Okevision provided at that time. She tended to watch the original Disney cartoon movies than watch it in national TVs which provided subtitles.

Day by day, her English kept improving. Her parents thought that if the child only relied on cartoon movie, the vocabularies would be limited to the language for children. So, parents decided to subscribe indihome which provided wider information. It is beyond expectation, the child started to watch English Youtubers who come from different countries. In this stage, the child kept practicing her English with her sister by acting as a Youtuber. This makes her and her sister improve their proficiency in English. They can speak English and be familiar with the vocabularies which appear in all different contexts, respond to the speakers properly and of course with the amazing accent and outstanding mimicry.

\section{CONCLUSION}

This study intended to explore the expressive language skills of a bilingual child from year to year. The table shows steady improvement from year to year, except in 2019. This might be owing to the fact that the data available in 2018 was of monologue type; so the subject's expressive production was very high with the MLU reaching 23.5. The monologue dialogue resulted in long utterances because no one would interrupt when the subject was speaking. Another factor could be the fact that the willingness of the subject to speak had increased over time. Overal, this study suggests that providing access to English-speaking media such as Youtube, cartoon network and the like could facilitate language acquisition. In fact, not only did the subject involved in the present study acquire the expressive language skills related to the children (toys, school stationary, animals, etc), but she also acquired vocabulary beyond children's world. What is more, the mimicry, the accent of the child was native-like, which further confirm the need for exposing young learners to native speakers model in the early age to successfully acquire the target language.

\section{References}

Borg, W. ., \& Gall, M. . (2003). Educational Research:an Introduction (7th ed.). Longman Inc.

Brown, R. (1973). A First Language. Allen and Unwin. 
Cresswell, J. . (1998). Qualitative Inquiry and Research Design:Choosing among five Tradition. Sage Publications.

Ellis, R. (2002). Does Form-Focused Instruction Affect the Acquisition of Implicit Knowledge? Studies in Second Language Acquisition, 24, 223-236. https://doi.org/10.1017/S0272263102002073

Kachru, Y., \& Nelson, C. (2006). World Englishes in Asian Contexts. World Englishes in Asian Contexts, 1-412.

Kid Sense Child Development Corporation. (n.d.). Expressive Language ( Using Words and Language ) - Kid Sense Child Development. childdevelopment.com.au

Krashen, S. (1981). Second Language Acquisition and Second Language Learning. Pergamon.

Merriam S, A. (2002). Qualitative research in practice: examples for discussion and analysis. Jossey-Bass.

Miller, J. F. (1981). The relation between age and mean length of utterance in morphemes. Journal of Speech and Hearing Research, 2(24), 154-161.

Mitchell, R., \& Myles, F. (2004). Second Language Learning Theories; Second Edition (2nd ed.). Hodder Arnold.

Richards, J. C., \& Schmidt, R. (2002). Longman Dictionary of Language Teaching and Applied Linguistics. British Library Cataloguing in Publication Data.

S. Deeksha. (2007). Language Development of a Child: 8 Main Factors Article (Issue June, pp. 3-5). http://www.psychologydiscussion.net/social-psychology-

2/language/language-development-of-a-child-8-main-factors/1392 